\title{
Green mining - use of hydraulic backfill in the Velenje Coal Mine
}

\author{
Jože Kortnik \\ Faculty of Natural Sciences and Engineering, University of Ljubljana, Ljubljana, Slovenia
}

SUMMARY: The paper presents the use of hydraulic backfill in the Velenje Coal Mine and the development of some procedures and devices for optimizing the basic properties of backfill mixtures. The technical, economic and environmental aspects of the hydraulic transportation of thick backfill mixtures (pastes) may be estimated only if the rheological properties are previously determined. For this purpose we developed the ball-pull test device, the tube viscosimeter and the pressure leaching test (PLT) equipment. A brief outline of tests of plastic and leaching characteristics and the method for determining the pressure gradient required for the specific flow of a time-independent non-Newtonian backfill mixtures and its application in the Velenje Coal Mine will be also presented.

Keywords: circle economy, green mining, longwall mining, hydraulic backfill

\section{INTRODUCTION}

Mining in the future need to be ecologically sustainable and economically effective. By establishing of closed ecological and technological circle of extraction, processing or energy transformation and returning mining waste materials into excavated open space it is possible to organize environment friendly, sustainable metal/non-metal/coal mining or circle economy in mining industry. By depositing mining waste into open underground spaces, earth surface can be disburdened. Suitable underground locations should take existing natural barriers into account otherwise some technical measures have to be taken to protect surrounding formation against adverse impact. The good results of this research should assure by selection of appropriate waste materials for suspensions preparation, transportation and deposition by proper technology. The perspective of coal mining in the Slovenia and in the world is mainly related to the introduction of environmentally friendly technologies into extraction and conversion into electricity. Given the fact that the content of ash and free sulfur in Slovenian coal is relatively high, it is necessary to take appropriate care of the products of combustion and flue gas cleaning during energy conversion in the Šoštanj Thermal Power plant. Use or return of large quantities of waste materials generated during the extraction and conversion of coal into electricity in excavated cave spaces significantly reduces the impact of excavation on the surface, improves the stress-strain state in the rock around the excavation and at the same time eliminates the load on landfills.

The perspective of coal mining in Slovenia and around the world is mainly related to the introduction of environmentally friendly technologies for coal extraction and conversion into electricity with the least possible impact on the environment. Given the fact that the content of ash and free sulfur in Slovenian coal is relatively high, it is necessary to take appropriate care of the products of combustion and flue gas cleaning during energy conversion in the Šoštanj thermal power plant. Useful use or return of large quantities of waste materials generated during the extraction and conversion of coal into electricity in excavated cave spaces significantly 
reduces the impact of excavation on the surface, improves the stress-strain state in the rock around the excavation and at the same time eliminates the load on landfills. We are talking about the quantities of several millions $\mathrm{m}^{3}$ of secondary waste materials that still need to be transported from the place of origin or the thermal power plant to the place of disposal or the excavated underground spaces (Bajželj, 1994).

The connected operation of a coal mine and a thermal power plant, with the return of secondary waste materials (Directive 2006/21/EC) to the underground premises of a coal mine, is called a closed ecological-technological cycle of electricity production or circular management of electricity production (EU Directive 2018/851). more friendly extraction of coal energy and its conversion into electricity. In the process of circular management in electricity production, the following negative impacts occur on the environment (Bajželj, 1994, 1995):

- In the phase of extraction:

- Change in the primary stress state in the rock,

- Deformations as a result of demolition processes,

- Deposition of pit tailings on the surface.

- In the phase of mineral processing:

- Disposal of separation tailings on the surface,

- Disposal of separation sludge on the surface,

- Discharge of technological water into the environment.

- In the phase of conversion of coal into electricity:

- Disposal of slag, gypsum, ash and fly ash,

- Emissions of flue gases into the environment $\left(\mathrm{SO}_{2}, \mathrm{NO}_{\mathrm{x}}, \mathrm{CO}_{2}\right)$.

Most of the negative impacts mentioned before can be eliminated by the introduction of Ecologically-technologically closed cycle of electricity production or circular economy or green mining as shown on Figure 1 below.

Taking into account the principle of waste management, that each waste producer must ensure the proper treatment of waste alone or with an officially recognized contractor (Directive 2008/98/EC or EU Directive 2018/851), the mining (coal extraction) industry has the advantage, that it can use the excavated open spaces for the disposal of practically all secondary waste materials generated in the process of extraction and energy conversion of coal into electricity, as well as secondary waste materials of other industries (see Figure1). In this respect, the connection of the coal mine and the thermal power plant into an ecologicallytechnologically closed cycle of electricity production or circular management in the production of electricity is an optimal solution.

With the introduction of ecologically-technologically closed cycle of electricity production or circular management in the production of electricity, we gain many advantages, such as (Bajželj, 1995, 2001):

- reduction of coal excavation losses,

- higher quality or calorific value of extracted coal,

- increasing productivity at excavations and in the preparation of preparatory lines,

- reduction of maintenance costs of cave facilities,

- reduction of the possibility of the collapse of hangingwall and the intrusion of water, sludge or liquid sands,

- smaller settlements on the surface,

- Avoid the construction of surface landfills for cave and separation tailings, ash, EF ash and gypsum, flue gas cleaning products.

These advantages can be achieved that the excavated open spaces (goaf areaa) are filled with backfill mixtures of appropriate physical and mechanical properties. The technology of preparation, transport and installation of backfill mixtures must meet the technological requirements of coal extraction. 


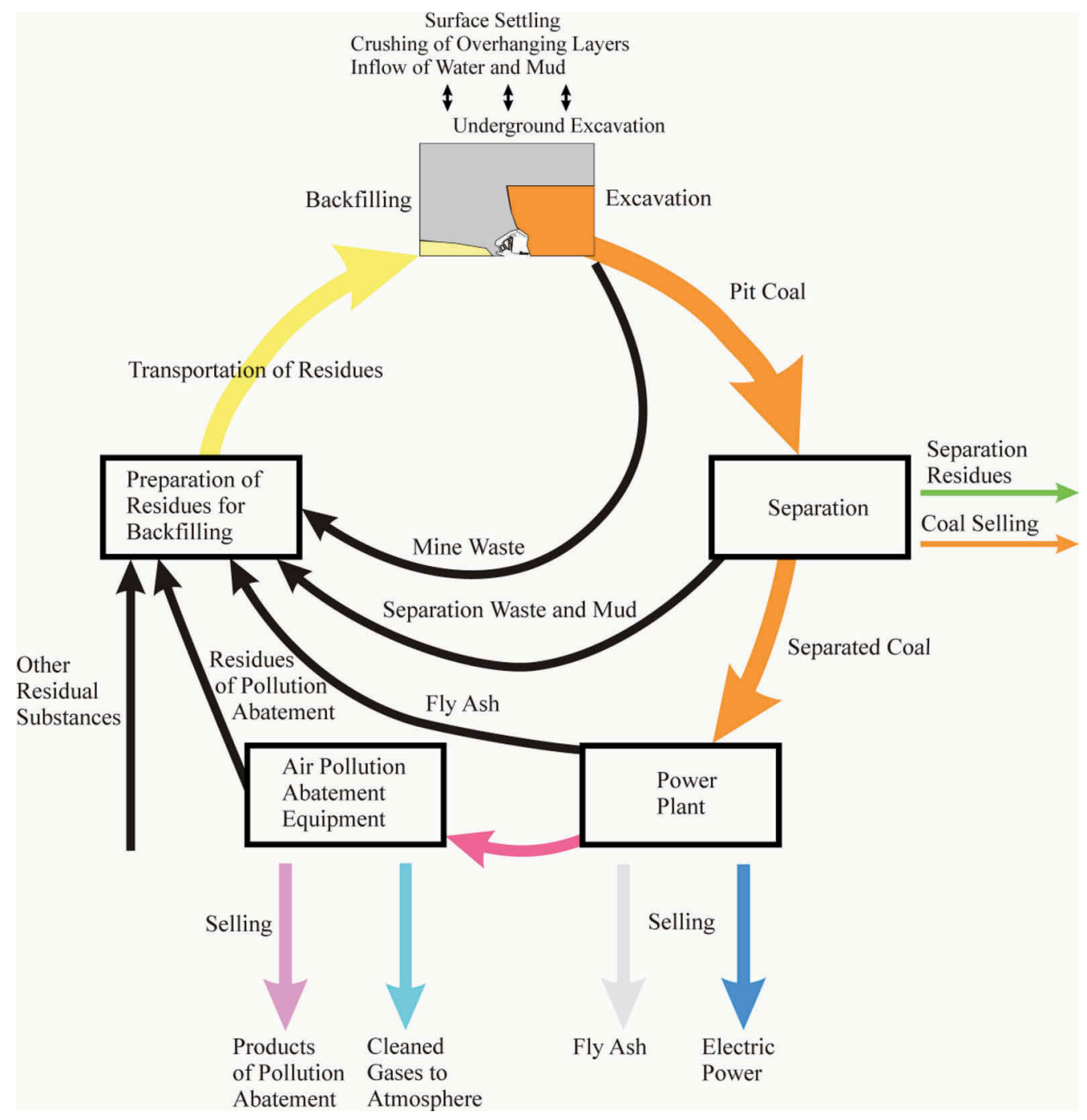

Figure 1. Ecologically-technologically closed cycle of electricity production or circular economy in the production of electricity from coal (Bajželj, 1994).

\section{DETERMINATION OF THE BASIC BACKFILL MIXTURES PROPERTIES}

Backfill mixtures suitable for transport over long distances of several kilometers and then for injection into the stope goaf area must have well-defined physical, chemical, transport and mechanical properties. By using various secondary waste materials of industry, we can positively influence the required properties of backfill mixtures, but we must take into account the principle without influence or environmental protection. Transporting large quantities of backfill mixtures over long distances requires the preparation of stable suspensions in rheological, chemical and mechanical terms, especially to prevent binding and settling of solid particles during transport and to ensure adequate strength of injected backfill mixtures into the collapsed old excavation work.

Backfill mixtures must achieve the appropriate properties in terms of (Kortnik, 2020): 
- Stability (thixotropy) and consistency (ball pull test, measurement of the paste spread on the glass plate)

- Transportability or pumpability (tube viscometer),

- Mechanical properties of injected backfill mixtures (high consolidometer),

- Leaching properties of injected backfill mixtures (pressure leaching test).

The stability (thixotropy) of the backfill mixture is determined by the ball-pull test. The self-made device is shown in Figure 2 (right). The time stability of the backfill mixture is determined by measuring the force required to pull the steel ball. The ball is located at the bottom of the measuring vessel. Measurements are performed at various time intervals after the preparation of the backfill mixture. The measured resistance force of the steel ball at different aging times of the backfill mixture is an assessment of the stability (thixotropy) as a consequence of the settling of solid phase particles in the backfill mixture mainly behave as time-independent non-Newtonian media. This can be expressed by the equation (1);

$$
F_{\max }=F_{\max }(t)
$$

Where it means,

$\boldsymbol{F}_{\boldsymbol{m a x}}$ the maximum value of the pull-out force of the steel ball which the suspension has at the bottom of the measuring vessel. Since the measured resistance force is the largest at the bottom of the measuring vessel, it was taken as relevant in estimating the dynamic viscosity coefficient.

$\boldsymbol{t}$ aging time or measurement time after preparation of the backfill mixture.

For easy, fairly accurate and fast determination of the consistency (resistance to shape change) of the backfill mixture, we used the measurement of the paste flow on the glass plate or paste flow value measurement. The measurement is taken from civil engineering standards (flow table test or flow test; ASTM C230, DIN EN 12350-5) and is performed at various time
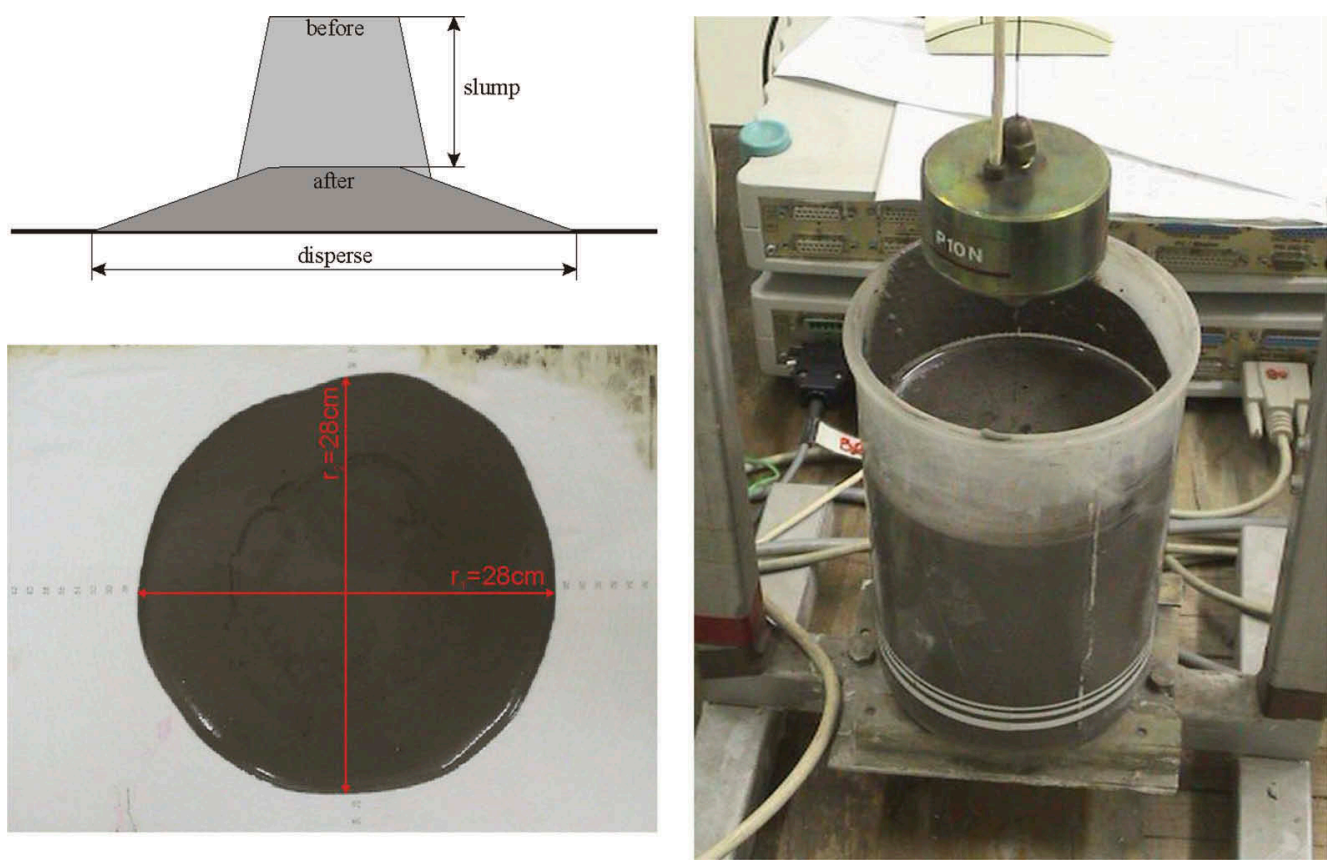

Figure 2. Ball-pull test device for the backfill mixture time stability determination by pulling the steel ball (right) and the slum test for determining the consistency of the backfill mixture by measuring the flow value (left). 
intervals. Place a metal cone with a volume of $0.34 \mathrm{dm}^{3}$ in the middle of a dry glass plate (1 $\mathrm{x} 1 \mathrm{~m}$ ) and fill it with the backfill mixture. Raise the cone quickly and measure the diameter resulting flow of the backfill mixture in two perpendicular directions, as shown in Figure 2 (left).

The backfill mixture flow value at different aging time is equal to the arithmetic mean of both readings; see equation (2);

$$
R_{\max }=\frac{r_{1}+r_{2}}{2}(t)
$$

Where it means,

$\boldsymbol{R}_{\text {max }}$ the maximum flow value of the backfill mixture at different time intervals. $\boldsymbol{r}_{1}, \boldsymbol{r}_{2}$ diameter resulting flow of the backfill mixture in two perpendicular directions. $\boldsymbol{t}$ aging time or measurement time after preparation of the backfilling mixture.

The transportability (pumpability) of the backfill mixture, as non-Newtonian suspensions, is determined by a laboratory test of pumping in a tube viscosimeter of our own production, which is schematically shown in Figure 3. The tube viscosimeter has two measuring sections, both $6 \mathrm{~m}$ long. The first has a tube diameter of $25.4 \mathrm{~mm}$ and the second of $50.8 \mathrm{~mm}$ (Bajželj, 1995). The velocity or flow of suspensions, density and temperature are measured in the part of the pipeline which is common to both sections. The purpose of the experiment is to measure the pressure losses when pumping the backfill mixture over long distances, to measure the starting pressures for different aging times of the backfill mixture in the pipeline in case of different pumping failures/interruptions and also to determine the pumping capacity of the backfill mixture.

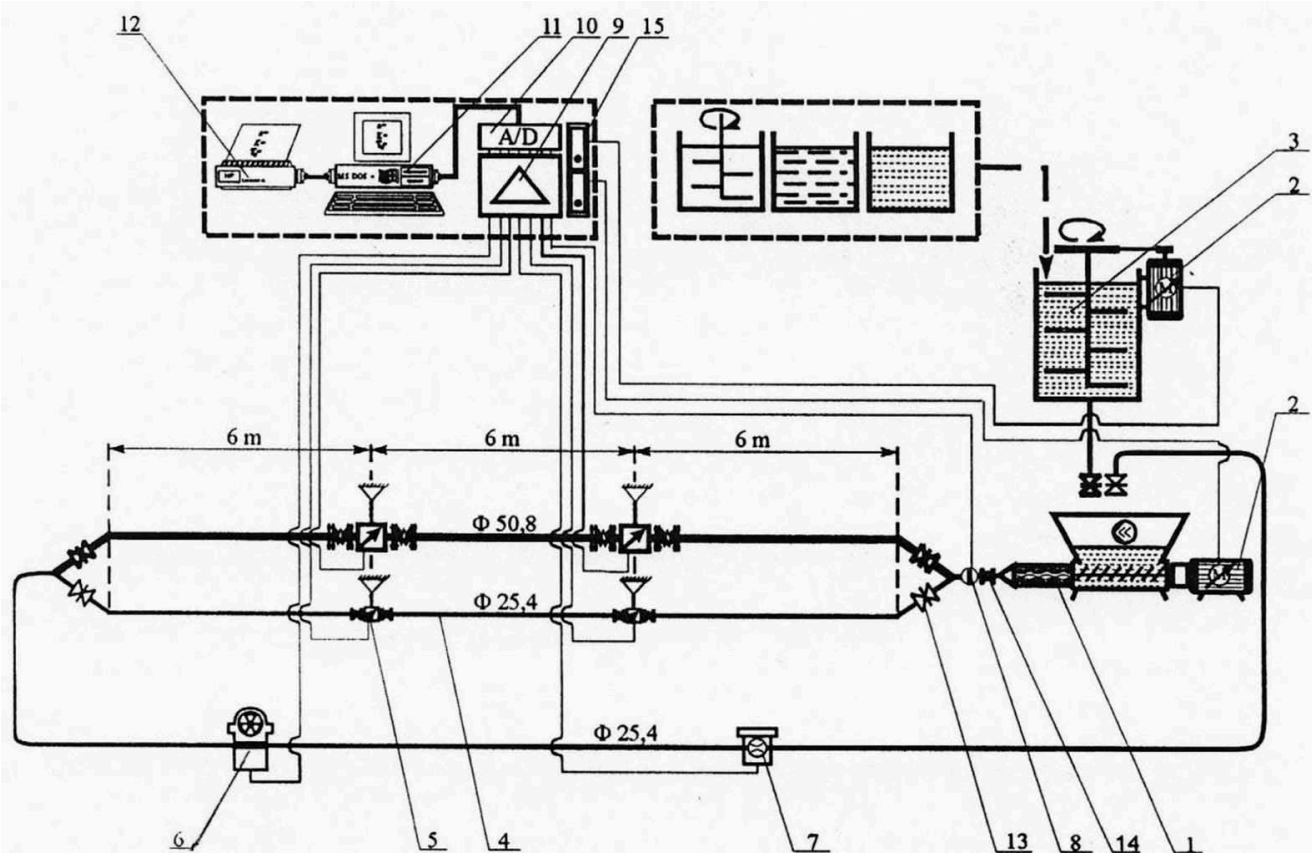

Figure 3. Shematic representation of the tube viscosimeter (Bajželj, 1995).

LEGEND: 1. Moineau pump; 2. squirrel cage motor; 3. mixer; 4. pipeline; 5. pressure gauge; 6. densimeter; 7. flowmeter; 8. thermometer; 9. carrier amplifier; 10. AD converter; 11 . PC computer $(486 / 66 \mathrm{MHz})$ : MS-DOS, Windows 95, DOS-ADC, Mathematica; 12. printer; 13. manual valve; 14. compensator; 15. inverter; 
The starting pressures for different aging times of the backfill mixture in the pipeline can be calculated by following equation (3);

$$
\Delta p_{\text {start }}=\frac{p_{2}-p_{1}}{l}(t)
$$

Where it means,

$\Delta \boldsymbol{p}_{\text {start }}$ starting hydraulic pump pressure per meter of the pipeline. $\boldsymbol{p}_{1}, \boldsymbol{p}_{2}$ measured pressure with pressure gauges $(25.4$ or $50.8 \mathrm{~mm})$ in tube viscosimeter. $\boldsymbol{l}$ length between two pressure gauges $(6 \mathrm{~m})$ in tube viscosimeter.

$\boldsymbol{t}$ aging time or measurement time after preparation of the backfilling mixture.

Leaching properties of injected backfill mixtures into the goaf area were determined using standard leaching tests (BS EN 14405:2017, etc.) and pressure leaching test (PLT) of own production, which is schematically shown in Figure 4. The use of a PLT enabled to establish similar conditions to those which are present during and after consolidation of injected backfill mixture into the goaf area behind the stope, and simulates leaching after the penetration of groundwater into the old excavated area consolidated with a backfill. The PLT was developed to study the leaching of partially bound granulated and solidly bound or monolithic samples. During measurement of the leaching parameters, PLTs can also be used to measure the initial hydraulic gradient, the coefficient of permeability, and the porosity of injected backfill mixtures.

The mechanical properties of injected backfill mixtures in the old excavation work are determined in laboratory in a high consolidometer equipped with an electronic displacement and compression force meter. Samples of crushed coal/hanging-wall material with injected backfill mixture from a high consolidator are aged for up to 60 days and measurements of basic geomechanical characteristics are performed in the laboratory. The measured values are shown in Table 1.

The measured values of the mechanical properties of the backfill were used to make mathematical geomechanical models of excavation with different hydraulic backfilling of the stope goaf area over entire width or only in areas of delivery and transport stope roads.
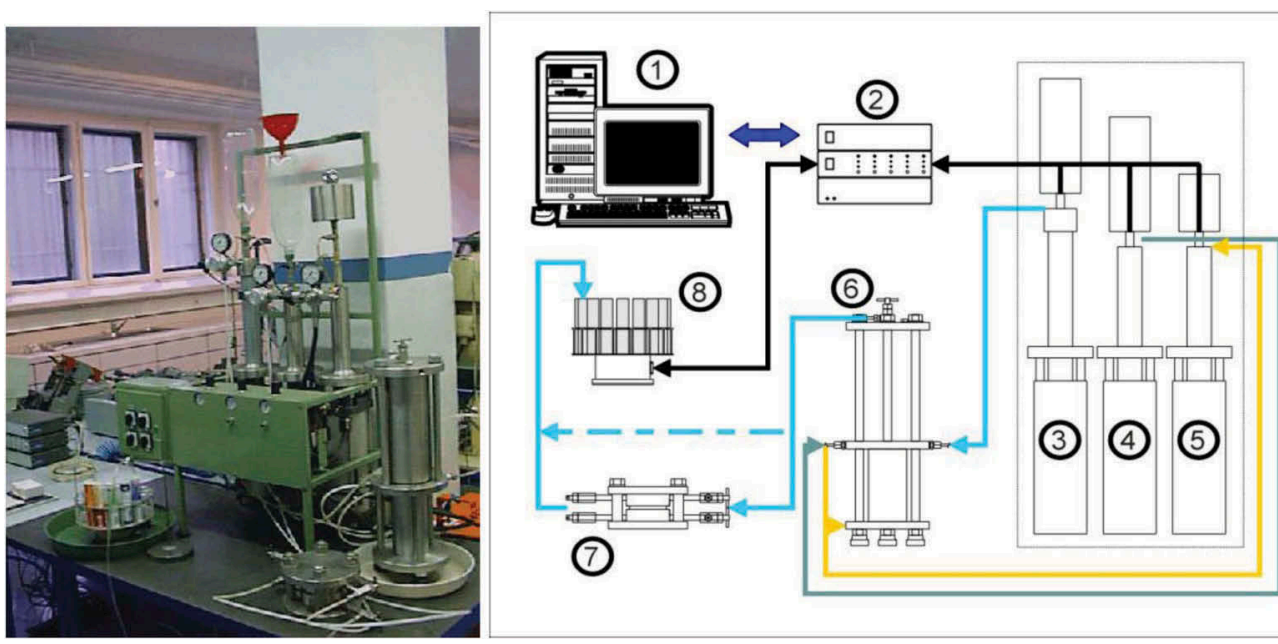

Figure 4. Schematic representation of pressure leaching test (PLT) equipment (Kortnik, 2000, 2003).

LEGEND: 1. PC computer (486/66MHz): MS-DOS, Windows 95, DOS-ADC, Mathematica; 2. AD converter; 3-5. Hydraulic drive unit; 4. vertical water injection unit into sample; 5. Sample axial pressure; 6. Pressure leaching cell; 7. Open diffusion cell; 8. Automate scale for separate eluate sampling (7x70ml); 
Table 1. Geomechanical characteristics of geological and backfilled hardened materials (Likar, 1994).

\begin{tabular}{|c|c|c|c|c|c|c|c|}
\hline & $\begin{array}{l}\text { Elastic } \\
\text { modulus }\end{array}$ & $\begin{array}{l}\text { Poisson's } \\
\text { ratio }\end{array}$ & $\begin{array}{l}\text { Shear } \\
\text { module }\end{array}$ & UCS & $\begin{array}{l}\text { Tensile } \\
\text { strength }\end{array}$ & $\begin{array}{l}\text { Shear } \\
\text { strength }\end{array}$ & $\begin{array}{l}\text { Specific } \\
\text { weight }\end{array}$ \\
\hline Geotechnical description & $\begin{array}{l}\mathrm{E} \\
(\mathrm{MPa})\end{array}$ & $v$ & $\begin{array}{l}\mathrm{G} \\
(\mathrm{MPa})\end{array}$ & $\begin{array}{l}\mathrm{N} \\
(\mathrm{MPa})\end{array}$ & $\begin{array}{l}\mathrm{T} \\
(\mathrm{kPa})\end{array}$ & $\begin{array}{l}\mathrm{R} \\
(\mathrm{kPa})\end{array}$ & $\begin{array}{l}\gamma \\
(\mathrm{kN} / \\
\left.\mathrm{m}^{3}\right)\end{array}$ \\
\hline Hanging-wall & 300 & 0.20 & 125 & 2.0 & 250 & 370 & 18.7 \\
\hline Coal seam & 200 & 0.35 & 75 & 4.0 & 400 & 730 & 13.0 \\
\hline Crushed coal above the stope & 3 & 0.35 & 1.1 & 0.3 & 30 & 55 & 11.0 \\
\hline $\begin{array}{l}\text { Crushed coal with injected backfill } \\
\text { mixture RIL-1 (paste) }\end{array}$ & 80 & 0.25 & 32 & 1.0 & 120 & 200 & 14.0 \\
\hline $\begin{array}{l}\text { Crushed coal with injected backfill } \\
\text { mixture RIL-1 (paste) }\end{array}$ & 40 & 0.28 & 16 & 0.7 & 100 & 155 & 13.0 \\
\hline
\end{tabular}

UCS . . Uniaxial compressive strength

\section{BACKFILLING SYSTEM IN VELENJE COAL MINE}

At the Velenje Coal Mine is excavated the coal seam, with a heat value of $8.4-10.5 \mathrm{MJ} / \mathrm{kg}$, in the form of an elongated lens, $8.3 \mathrm{~km}$ long, $2.5 \mathrm{~km}$ wide and with a maximum thickness of $170 \mathrm{~m}$ at a depth of 200 to $500 \mathrm{~m}$. Coal has been mined here since 1875 (146 years of operation) in several mine-fields as Škale mine, Pesje mine, Preloge mine, Gabrke mine, etc. The excavation technology was developed through simple excavation methods to the highproductive Velenje long-wall mining method (average production 4 million t/year) with fully mechanized equipment (hydraulic shield support with electro-hydraulic control, two-drum cutting extraction machine, front chain conveyor frequency and directional, etc.), the possibility of vertical and horizontal concentration of excavations and the possibility of backfilling of the excavated space behind the stope (VCM, 2020).

Backfilling was in Velenje Coal Mine carried out intensively mainly in the period of years 1992-2004 at stopes k. $+157, \mathrm{~B} / 5 \mathrm{~b}, \mathrm{~B} / 6, \mathrm{~B} / 6 \mathrm{~b}$ in the Škale mine, stope D k.+25 in the Pesje mine, at stope L2 and stopes G1/A, G1/B and G1/C in the north-western part of the Preloge mine (Gaberke mine). A schematic representation of the backfilling system in the Škale mine is shown on Figure 5. and the backfilling mixture injection into the stope goaf area is shown on Figure 6. It was found that the construction of new level excavation roads under areas backfilled with backfill mixtures (pastes) is significantly safer, and with the use of lighter support measures also faster, mainly due to improved geotechnical conditions by backfilling hardened rock. Furthermore, it was found also that the disturbed coal seam hardened with embossed backfill mixture can represent a technical solution to improve geotechnical conditions in continuing coal mining on lower levels towards the seam floor-wall and also in preventing oxidation processes of coal in stope safety pillars during excavations on the level (Lajlar, 2004).

The backfill mixtures receipes were adapted mainly to the better transport conditions (lowest pumping pressure), the requirements for instalation into the old excavation work (easy flow of the backfill mixture), the achievement of the required final geomechanical characteristics and the lowest impact of the eluates on the environment (solidification/consolidation of backfill mixture), especially the hydrosphere. The backfill mixtures were made of various materials such as fly ash, cement, lime, bentonite and various additives to inhibit or accelerate the binding.

The backfilling technology (receipe RIL-1; see Table 2.) used on stope B/5b in the Škale mine first consisted mainly of three main phases (see Figure 5): the phase of backfilling mixtures preparation in the surface mixing station, the phase of hydraulic transport of the backfill mixture by pipeline to the stope and the phase of backfill mixture injection into the goaf area (Bajželj, 1994). The achieved results of backfilling the goaf areas of stopes B5/b and B6/b are 


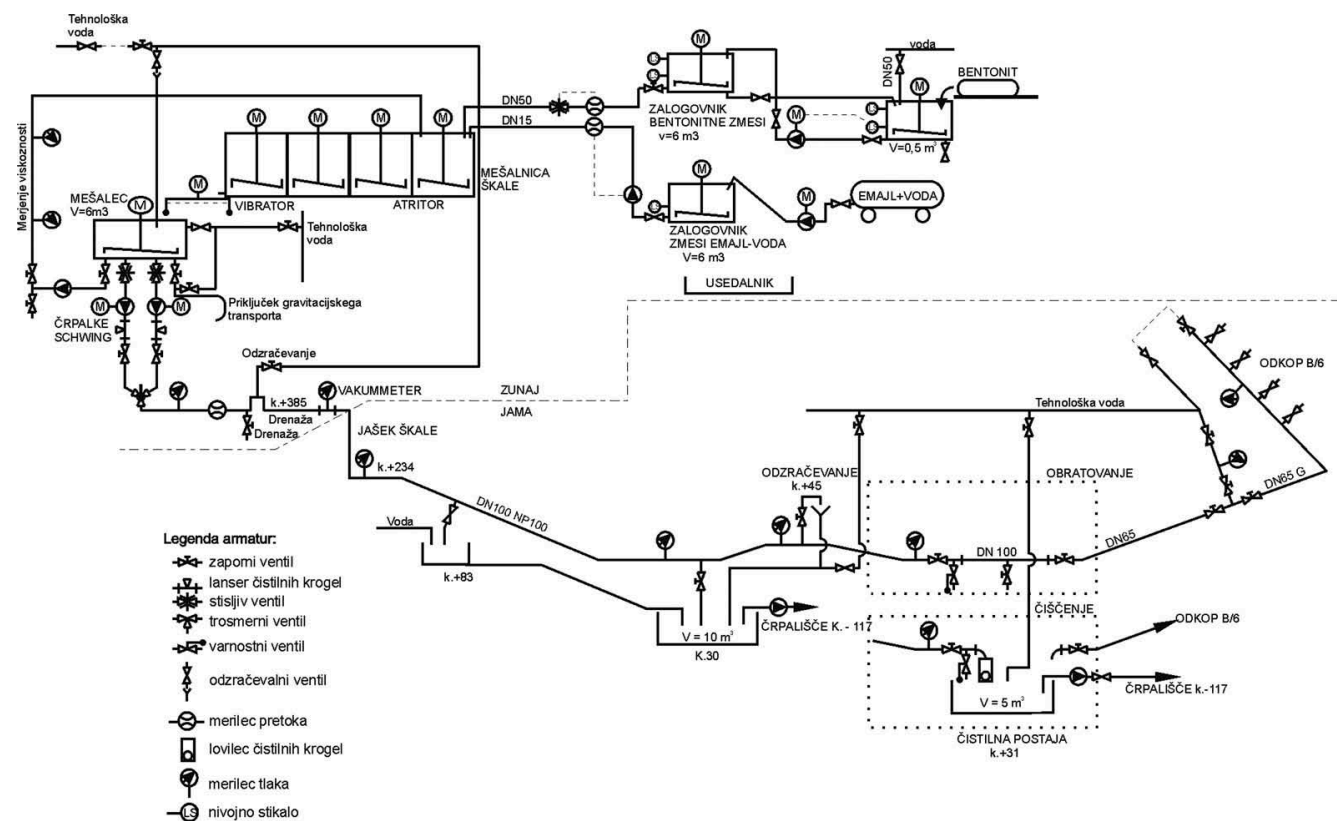

Figure 5. Schematic representation of backfilling system in the Škale mine (Bajželj, 1995).

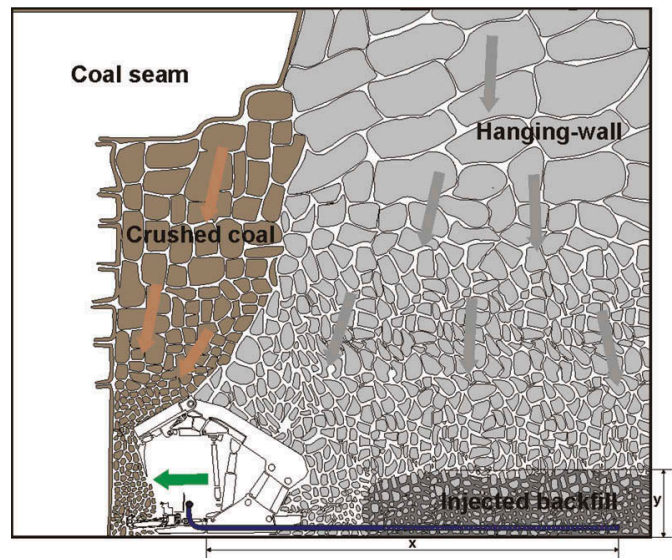

Figure 6. Schematic representation of backfilling the stope goaf area with the backfill mixture.

collected in Table 3 and Figure 7 graphically shows the heights of the injected backfill mixtures into the stope goaf area $\mathrm{B} 5 / \mathrm{b}$ (average $19 \mathrm{~cm} / \mathrm{m}^{2}$ ).

The backfill technology (RIM-UNI recipe; see Table 2) used on stope D k.+25 in Pesje mine, on stope L2 and stopes G1/A, G1/B and G1/C in the north-western part of Preloge mine was consists of five main phases such as the first phase of RIM-UNI/A liquid backfill mixture preparation at the surface mixing station, the phase of liquid backfill hydraulic transportation by pipeline to the underground mixing station, the phase of preparation of the RIM-UNI/B thick backfill mixture in the underground mixing station, the phase of hydraulic transport of the thick backfill mixture by pipeline to the stope and and the phase of thick backfill mixture injection into the goaf area of the stope. The achieved results of backfilling 
Table 2. Recipes for backfill mixtures used at the Velenje coal mine.

\begin{tabular}{llll}
\hline Backfill mixture/receipe & RIL-1 & RIM-UNI/A & RIM-UNI/B \\
\hline Flow value & $26 \mathrm{~cm}$ & $40 \mathrm{~cm}$ & $25 \mathrm{~cm}$ \\
Volume weight & $1.55 \mathrm{t} / \mathrm{m}^{3}$ & $0.82 \mathrm{t} / \mathrm{m}^{3}$ & $1.40 \mathrm{t} / \mathrm{m}^{3}$ \\
Ratio water:solid & $37: 63$ & $45: 55$ & $40: 60$ \\
Fly ash & $81.8 \%$ & $87.6 \%$ & $69.9 \%$ \\
Red-mud Kidričevo & $7.3 \%$ & - & - \\
Hydrated lime Zagorje & $7.3 \%$ & $8.0 \%$ & $6.3 \%$ \\
Bentonite IBECO S-80 & $3.6 \%$ & - & - \\
Portland Cement & - & $4.0 \%$ & $3.2 \%$ \\
R-2 retarder TKK & - & $0.4 \%$ & $0.3 \%$ \\
Mortar M50 & - & - & $8.3 \%$ \\
Bentonite gel (solid:water=1:9) & - & - & $11.9 \%$ \\
Thickener L TKK & - & - & $0.1 \%$ \\
\hline
\end{tabular}

Table 3. Achieved parameters of backfilling with backfill mixtures (pastes) on stopes B5/b, $\mathrm{B} 6 / \mathrm{b}, \mathrm{G} 1 / \mathrm{A}$ and $\mathrm{G} 1 / \mathrm{B}$.

\begin{tabular}{llclll}
\hline Stope No. & & B5/b & B6/b & G1/A & G1/B \\
\hline Backfilling operation & $($ days $)$ & 31 & 40 & 95 & 48 \\
Injected paste quantity & $\left(\mathrm{m}^{3}\right)$ & 947 & 2,389 & 3,606 & 2,097 \\
Max. paste injected heigh & $\left(\mathrm{cm} / \mathrm{m}^{2}\right)$ & 24 & 65 & 70 & 51 \\
Averg. paste injected height & $\left(\mathrm{cm} / \mathrm{m}^{2}\right)$ & 19 & 25 & 38 & 30 \\
\hline
\end{tabular}
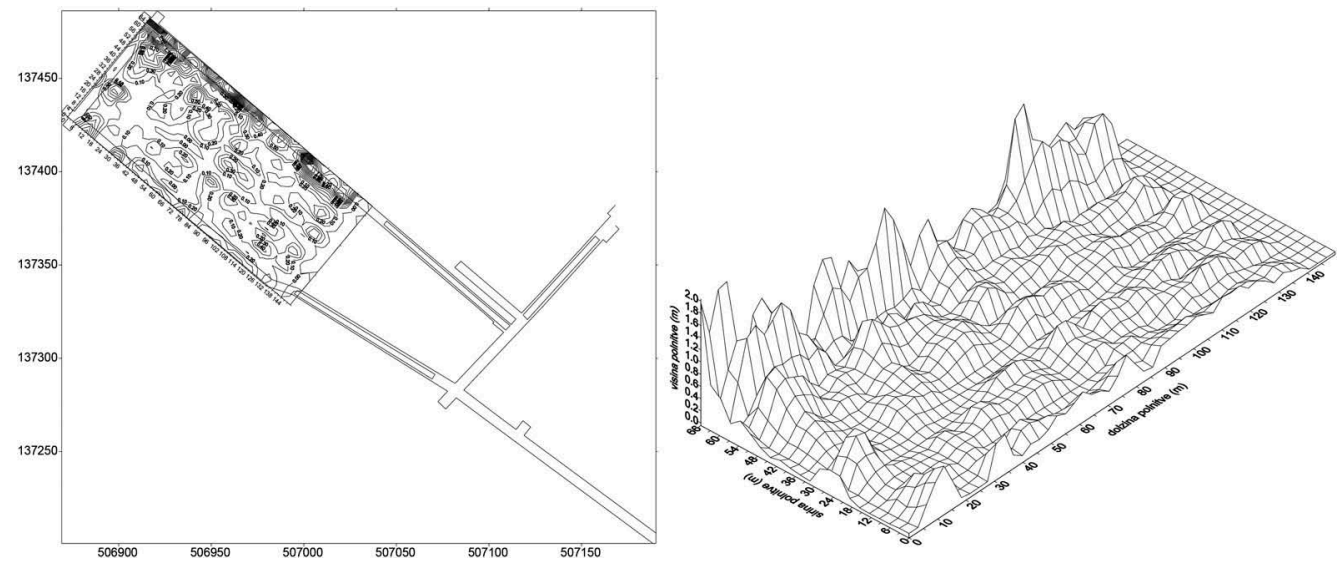

Figure 7. Graphic representation of backfilling results over entire width on the stope $B 5 / b$ (Bajželj, 1995).

the goaf areas of stopes G1/A and G1/B are collected in Table 3 and Figure 8 graphically shows the heights of the injected backfill mixtures into the stope goaf area G1/A (average $30 \mathrm{~cm} / \mathrm{m}^{2}$ ).

The main purpose of the backfill introduction in the Velenje Coal Mine were:

- consolidation of the excavated old area behind the stope and improvement of geotechnical conditions for the construction of lower-lying floor excavation road, 

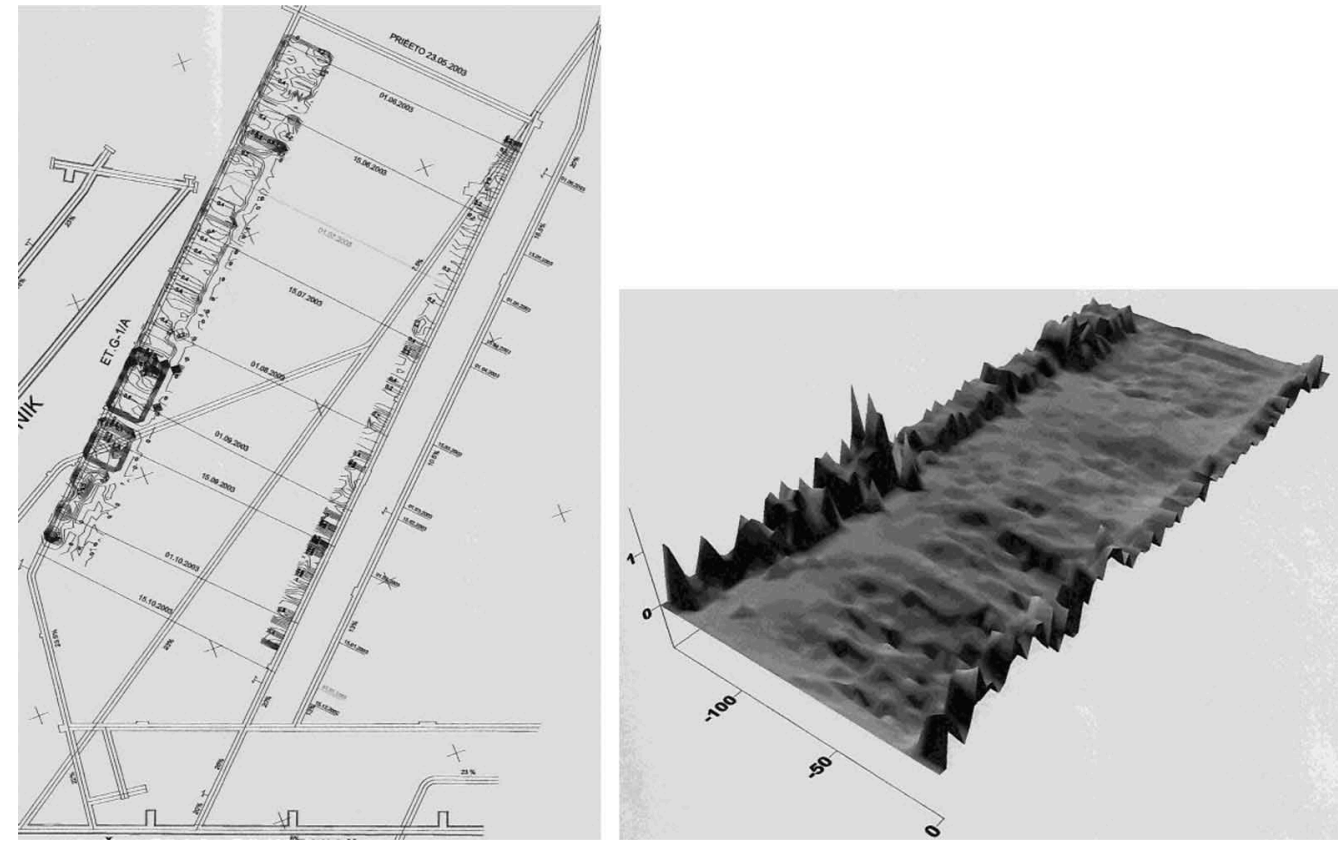

Figure 8. Graphic representation of backfilling results on stope G1/A only in close areas of delivery and transport stope roads (Kortnik, 2020).

- prevention of oxidation processes in coal in safety columns during the stope excavation,

- construction of an indicative backfill to control the excavation height on the lower-lying stopes,

- return of secondary materials (fly ash, gypsum, secondary materials of industry) to the underground openings and solidification of backfilled areas.

Despite many established advantages, the backfill method in the Velenje Coal Mine was intensively used until the end of 2004, but then due to relatively good geomechanical conditions and due to the reduction of excavation costs in the north-western part of Preloge mine, the backfilling method was gradually abandoned.

\section{SUMMARY}

Mining methods with backfill enable the introduction of Circular economy or closed Ecological-Technological circle and thus Environmentally friendly mining or Green mining of mineral resources. This means that various waste materials generated during the extraction and processing of mineral raw materials are used for the preparation of backfill mixtures for filling and consolidation of open underground spaces, and at the same time we reduce the quantities of these substances deposited in surface landfills. In addition, some secondary industrial waste materials can be also used to achieve the required properties of backfill mixtures, in doing so, we are obliged to observe the principles of environmental protection. The technical, economic, environment and other aspects of the thick backfill mixtures (pastes) may be estimated only if their rheological hydraulic transportation properties are previously determined.

The basis of all backfill mixtures used in Velenje Coal Mine is fly ash from the nearby Šoštanj Thermal Power Plant, to which we add various additives and secondary materials of industry to ensure stability. The stability of the backfill mixture is greatly influenced by the 
average particle size, their granulation distribution and proportions. It has been found that an appropriate time-stable backfill mixture is achieved by adding secondary materials with the smallest possible particle size. The suitability of backfill mixtures is determined on the basis of investigations of the physical and chemical properties of individual components as well as whole backfill mixes. For backfill mixtures, depending on the mode of transport, method of filling and required geotechnical properties after installation, stability (thixotropy), rheological properties, pressure gradient of pumping, mechanical properties, leachability as well as the potential possibility of migration of impurities into the environment are need to be determined. For this purpose we developed the ball-pull test, tube viscosimeter and pressure leaching test (PLT) equipment which enables optimization of backfill mixtures and thus also modification of mining method with backfilling. In case of difficult geomechanical conditions, the backfilling method can be reused in the future again and ensure competitive advantages of the Velenje Coal Mine.

\section{BIBLIOGRAPHY}

Bajželj, U., Medved, M., Oprešnik, B., Jenko, B. \& Križan, J. (1994). Avtomatization of the technological process of injecting paste made of fly ash into the goafs in the Velenje lignite mine, APCOM'94, Bled, pp. 13.

Bajželj, U., Medved, M., Oprešnik, B., Kortnik, J. \& Likar, J. (1994). The return of waste materials into active mines. Proceeding of $2^{\text {nd }}$ International Conference on Tunnel Construction and Underground Structures, Ljubljana, pp. 20.

Bajželj, U., Likar, J., Medved, M., Oprešnik, B., Kortnik, J. (1995). Priprava in namen uporabe pepelnih past ter tehnologija vtiskanja v razrušene odkopane prostore. - Rudarsko posvetovanje ob 34. skoku čez kožo, Ljubljana, p. 73-97 (in Slovene).

Bajželj, U., Žerdin, F., Medved, M., Veselič, M., Šubelj, A., Fece, V., Dervarič, E. \& Veber, I. (1995). Ecological Aspects of Thick Coal Mining - Report on accomplishment of the Slovenian-American Research Project. IRGO, Ljubljana, pp. 29.

Bajželj, U., Kortnik, J. (2001). Tehnični aspekti uporabe odpadnih snovi v rudarstvu. Zbornik 37. skoka čez kožo, Ljubljana, pp. 13 (in Slovene).

Kortnik, J. (2000). Use of the pressure leachate control test for the selection of multi-barrier disposal systems. Proceedings of $5^{\text {th }}$ International symposium on Environmental Geotechnology and Global Sustainable Development, 17.-23. August 2000, Belo Horizonte, Minas Gerais, Brazil, pp. 6.

Kortnik, J. (2003). Backfilling waste material composites environmental impact assessment. Journal of the South African Institute of Mining and Metallurgy, July/August 2003, p. 391-396.

Kortnik, J. (2020). Circle Economy in mining industry - Underground mine hydraulic backfill use in an ecologically and technologically closed circle. Proceedings of $2^{\text {nd }}$ International Multidisciplinary GeoScience Conference - IMGC2020, 8.-9. October 2020, p. 11-21.

Lajlar, B. (2004). Zapolnjevanje in utrjevanje s pepelnimi mešanicami pri odkopavanju severozahodnega predela jame Pesje - seminarska naloga. UL-NTF, Ljubljana, pp. 30 (in Slovene).

Likar, J. (1994). Rezultati geotehničnih raziskav možnosti utrjevanja starega dela v Rudniku lignita Velenje poročilo. IRGO, Ljubljana, junij 1994, pp. 30 (in Slovene).

VCM - Velenje Coal mine, [visit on: 18.09.2020]. Retrieved from: http://www.rlv.si/en/. 